\title{
Clinical Stage Evaluation at Diagnosis of Prostate Cancer at Urology-Andrology Clinic Cnhu-Hkm Cotonou
}

\author{
Hounnasso Prince Pascal' ${ }^{1}$, Avakoudjo Josué Dejinnin Georges ${ }^{1}$, \\ Soumanou Fouad Kolawalé Yde ${ }^{*}$, Koussouhon Manoël Dossavi1, \\ Yevi Dodji Magloire'2, Vodonou Alexandre1 \\ ${ }^{1}$ Urology-Andrology, Faculty of Medecine, CNHU-HKM, Cotonou, Benin \\ ${ }^{2}$ Urology-Andrology, Faculty of Medicine, CHD-OP, Porto-Novo, Benin \\ Email: soumfou@yahoo.fr
}

Received 20 February 2015; accepted 9 March 2015; published 11 March 2015

Copyright (C 2015 by authors and Scientific Research Publishing Inc.

This work is licensed under the Creative Commons Attribution International License (CC BY). http://creativecommons.org/licenses/by/4.0/

(c) (i) Open Access

\begin{abstract}
Aims: To evaluate the clinical stage at diagnosis of prostate cancer. Materials and Methods: This study was retrospective and descriptive from January 2008 to June 2013. Patients who were diagnosed with prostate cancer wereinvolved and confirmed by clinical examination anatomopathological screening. They also realized a total serum PSA, a bladder-prostatic and abdominal ultrasound. Results: Average age was seventy years, ranging from fifty years to seventy years. The general status of our patients was satisfactory in $78 \%$ of cases. Main symptoms were dysuria and frequencyin $96 \%$ and $86 \%$, respectively. Family past history of prostate cancer were found in $24 \%$ of cases. Twenty-three patients $(43 \%)$ had a total serum PSA $\geq 100 \mathrm{ng} / \mathrm{ml}$. Adenocarcinoma was the main histological type. Grades 1 and 4 were the most frequent. Thirty-three patients $(66 \%)$ had a Gleasonscore betwen [2]-[6]. Forty-four patients (88\%) had locally advanced and metastatic desease. The D'Amico score was identified in six patients but 3 and 2 patients were low risk and intermediate riskrespectively. Finally, 1 patient was high risk. Conclusion: Prostate cancer remains elderly man cancer. It was discovered in locally advanced and metastatic desease in this series. This diagnosis was late in the majority of cases.
\end{abstract}

\section{Keywords}

Prostate Cancer, Anatomical Pathology, Total Serum PSA

\footnotetext{
${ }^{*}$ Corresponding author.
} 


\section{Introduction}

Prostate cancer is a disease of the elderly and is a public health problem elsewhere. It's the most common cancer in men over 50 years. Its frequency has significantly increased these recent years, due in part to the rise of life expectancy of the population, coupled with the adoption by developing countries with a western lifestyle characterized by rich diet calories and lack of physical training [1]. Moreover, with the increase in life expectancy, one man in eight has a risk of carrying a prostate cancer during his lifetime. But only one man in thirty will die from complications related to disease progression. Thus, the number of asymptomatic men in which prostatic cancer is diagnosed, following a total serum PSA assay is increasingly important [2]. This study aims to clarify the clinical stage at diagnosis of prostate cancer at urology-andrology clinic of CNHU-HKM Cotonou.

\section{Materials and Methods}

This was a retrospective descriptive study referred, covering a period of five and a half years, running from January 2008 to June 2013. Patients with a diagnosis of prostate cancer were involved and were confirmed by Digital Rectal Examination (DRE) and a total serum PSA, bladder-prostatic and abdominal ultrasound, and anatomopathological screening were included in this study.

For the sampling of the studied population, we used non-probability method. We obtained a sample of fifty cases.

The following items were studied: age, discovery circumstances, past history, prostate status on Digital Rectal Examination (DRE), metastasis locations, histological type, Gleason score, TNM classification of 2009 and D’Amico score.

Data analysis were treated by EPI INFO Software 3.5.1.

\section{Results}

The average age of our patients was 70 years (50 - 90 years) (See Figure 1 ).

The general status of patients was satisfactory in $78 \%$ of cases $(n=39)$ and altered in $22 \%(n=11)$. The most common symptoms dysuria and frequency were in respectively $96 \%$ and $86 \%$ of cases. Other symptoms such as urinecomplete retention, hematuria, and bone pain were noted in respectively $32 \%, 14 \%$ and $14 \%$ of cases. Other symptoms such as infectious complications (12\%), constipation (8\%), lower extremities edema (6\%), and dyspnea (4\%) were discovered too. Finally, on the prostatectomy pieces and total serum PSA rising in respectively $26 \%$ and $10 \%$ of cases the prostate cancer has been discovered.

In the past history of the patients, a prostatectomy and prostate cancer in the family were noted in respectively $26 \%$ and $24 \%$ of cases.

\section{Prostate status:}

DRE has indicated the prostatic nodules and adenoma in respectively $30 \%$ and $26 \%$. It was normal in $10 \%$ and suspected carcinoma in $4 \%$ of cases.

\section{Total serum PSA:}

Total serum PSA varied between $15 \mathrm{ng} / \mathrm{ml}$ to $1000 \mathrm{ng} / \mathrm{ml}$. Six patients (12\%) had total serum PSA level between 10 - $30 \mathrm{ng} / \mathrm{ml}$, while twenty-one (42\%) had a total PSA level of between $30-100 \mathrm{ng} / \mathrm{ml}$. Finally twentythree patients (43\%) have had a total serum PSA $\geq 100 \mathrm{ng} / \mathrm{ml}$.

\section{Ultrasound imaging:}

Hypoechoic imaging was noted in $78 \%(\mathrm{n}=38)$ with hydronephrosis in $22 \%(\mathrm{n}=11)$. Pelvic lymphnodes

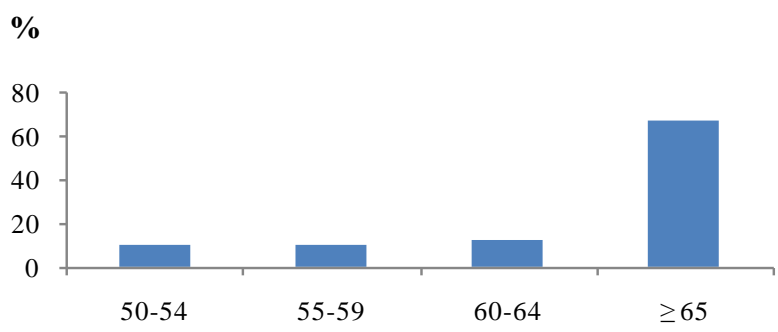

Figure 1. The distribution of the patients according age. 
bones, lungand livermetastases were observed in $4 \%$ and $2 \%$ of cases.

\section{Anatomopathological screening:}

Histological type:

Adenocarcinoma was the only one histological type found.

\section{Histological grade:}

Grades 1 and 4 were the most frequent. Grade 5 was not found in this series. (See Table 1)

Thirty-three patients (66\%) had a Gleason score between [2]-[6].

\section{Metastasis:}

\section{Bone metastasis:}

Pelvic bones were invaded by metastasis in $34.3 \%$ while lumbar spine was interested in $34.3 \%$.

\section{Lung metastasis:}

Twenty-one patients have realized the chest X-ray. Two (9.5\%) of these imaging have showed the lung metastasis.

\section{Lymphnodes metastasis:}

No lymphnodes metastasis was found.

TNM classification:

See Table 2.

D’Amico score:

3 and 2 patients were low risk and intermediate respectively. Finally, 1 patient was high risk.

\section{Discussion}

We noted an average age of 70 years (50 - 90 years). Amégbor et al. [1] in Togo in 2003 reported 70 years (45 95 years). However, cancer can be diagnosed in younger subjects especially. In this case, the disease is aggressive and has a much faster evolution. Indeed, according to Aus et al. [3], a prostate cancer diagnosed before 65 years, kills three out of four times when it is not treated. Discovery circumstances were similar to those of Amégbor et al. [1] in Togo in 2003, who reported dysuria and frequency in 92\% of cases. Prostate cancer develops especially at the peripheral zone away from the urethra [4]. This could explain the proportion of $10 \%$ of chance discovery characterized by an isolated elevation of total serum PSA. This anatomical feature could be a factor for a late discovering stage. As for McNeal transitional zone, it is characteristic of cancer association with benign prostatic hyperplasia (BPH) [4]. Thus, in $26 \%$ of case, cancer was discovered after a prostatectomy for $\mathrm{BPH}$. The family history of prostate cancer has generally not been clarified in our patients. It would be useful to assess the genetic or familial risk factors [5]. The general status of the patients was altered in $22 \%$ of cases. In Senegal, Niang et al. [6] found, greater proportion estimated to $44 \%$. The alteration of the general status is based on three elements: asthenia, anorexia and weight loss. Digital rectal examination was suspect of prostate cancer in 64\%. This result is lower than the $87 \%$ recorded by Niang et al. in Senegal [6]. Digital rectal examination still remains an important diagnostic tool and it should not be substituted to an isolated total serum PSA rise. Because, according to Catalona et al. [7], 10\% of cancers are disclosed by the clinical examination, while the value of total serum PSA is less than the normal threshold value. However, rectal Touch does not appreciate the microscopic capsular reached. Patients in our study have elevated PSA between 15 and $1000 \mathrm{ng} / \mathrm{mL}$. Our results are similar to those of other authors [1] [6]. Indeed, according to Stamey et al. [8], the stage of cancer revelation is highly correlated to the value of initial total serum PSA. Thus, beyond $30 \mathrm{ng} / \mathrm{mL}$, the cancer is already at

Table 1. Histological grades distribution.

\begin{tabular}{ccccc}
\hline \multirow{2}{*}{ Grades } & A & \multicolumn{1}{c}{ B } & Percentage (\%) \\
\cline { 2 - 5 } & Effective (N:50) & Percentage (\%) & Effective (N:50) & 6 \\
$\mathbf{1}$ & 26 & 52 & 3 & 18 \\
$\mathbf{3}$ & 6 & 12 & 9 & 26 \\
$\mathbf{4}$ & 1 & 2 & 13 & 50 \\
$\mathbf{5}$ & 17 & 34 & 0 & 0 \\
\hline
\end{tabular}


Table 2. Patients distribution according to TNM 2009.

\begin{tabular}{ccc}
\hline & Effective $(\mathbf{N}=\mathbf{5 0})$ & Percentage (\%) \\
Tumor (T) & 13 & 26 \\
T1a + T1b & 5 & 10 \\
T1c & 15 & 30 \\
T2a + T2b & 15 & 30 \\
T2c & 2 & 4 \\
T4 & & \\
Node (N) & 42 & 84 \\
NX & 6 & 12 \\
N0 & 2 & 4 \\
N1 & & \\
Metastasis (M) & 29 & 58 \\
Mx & 6 & 12 \\
M0 & 12 & 24 \\
M1b &
\end{tabular}

advanced stage non curable with metastasis risk rising [9]. The lack of financial means has limited patients achieving further investigations. In addition, they are required based on clinical signs. These arguments may explain disparities in the distribution of paraclinical features. The thoraco-abdominal-pelvic CT and magnetic resonance imaging are still rarely used in our context. Yet they are essential in assessing the extent of the tumor and thus they allow having appropriate therapeutic indications [10]. There is no specific ultrasound image of the prostate cancer. In addition, the normality of the endo-rectal ultrasound does not eliminate prostate cancer diagnosis [11]. In its local domain, the tumor invades the lower ureter. This creates an obstacle responsible of one or two sited ureterohydronephrosis. The latter will gradually lead to obstructive renal failure which is a poor prognosis [12]. Prostate cancers are mostly osteophilic [13]. This could explain our results. Search pelvic lymphadenopathy was some of what specified in the sonographic assessment of our patients. Adenocarcinoma was only the histological type found in our study. Our results are similar to those of other authors [1] [3]. Gleason score were mostly between [2]-[6], in 66\%. In 2000, Prost et al. [14] found, in France, a similar proportion estimated at 50\%. Between 1988 and 1999, Rigaud et al. [15] also reported in France, an estimated rate of 15\%. Tumors with a high Gleason score had more fast evolved and early metastases [5]. X-ray imaging allowed recovering 35\% of bone metastasis, where clinical examination evoked only 14\%. Similarly, between 1988 and 1999, Rigaud et al. [15] recorded in $62 \%$ bone metastasis against bone pain $28 \%$. Bone scintigraphy is the gold standard for detecting bone metastasis. It identifies bone abnormalities much faster than plain radiography [15]. According to Stamey et al. [8], the cancer is discovered at a localized stage for a PSA less than $30 \mathrm{ng} / \mathrm{mL}$. Between 30 and $100 \mathrm{ng} / \mathrm{mL}$, prostate cancer is coraleted to advanced stage with node metastasis. Beyond $100 \mathrm{ng} / \mathrm{mL}$, there was the presence of bone metastasis. These results differ from those of Rigaud et al. in France [15] and Niang et al. in Senegal [6]. Nevertheless, these studies have in common difficulty assessing regional lymphnodes (NX). Indeed, only the dissection can confirm nodals status of prostate cancer [16]. Difficulty making a clear distinction between the proportions of the three categories of D'Amico is due to lack of sensitivity and specificity of the bladder and prostate ultrasound [17]. Yet the bladder-prostatic ultrasound is still widely used in hospitals, to the detriment of computed tomography and magnetic resonance imaging.

\section{Conclusion}

Prostate cancer remains elderly man cancer. Most the patients came at the stage of locally advanced and metastatic desease. The diagnosis was made too late characterized by high level total of serum PSA and rise of multifocal bone metastases. 


\section{Conflict of Interest}

No conflict was encontered.

\section{References}

[1] Amegbor, K., Yao Seddoh, T., Tengue, K., Napo-Koura, G., Songne-Gnamkoulamba, B. and James, K. (2009) Epidemiology and Histopronostic of Prostatic Cancer in Togo: About 202 Cases Diagnosed at the Laboratory of Pathology of the Tokoin Teaching Hospital of Lome. Progres en Urologie, 19, 112-115.

http://dx.doi.org/10.1016/j.purol.2008.10.008

[2] Soulie, M. (2003) Cancer Epidemiology. Progres en Urologie, 13, 1261.

[3] Aus, G., Hugosson, J. and Norlen, L. (1995) Long-Term Survival and Mortality in Prostate Cancer Treated with Non Curative Intent. Journal of Urology, 154, 460-465. http://dx.doi.org/10.1016/S0022-5347(01)67074-5

[4] McNeal, J. (1968) Rjegional Morphology and Pathology of the Prostate. American Journal of Pathology, 49, $347-357$.

[5] Soulie, M., Barre, C., Beuzeboc, P., Chautard, D., Cornud, F., Eschwege, P., Fontaine, E., Molinie, V., Moreau, J.L., Peneau, M., Ravery, V., Rebillard, X., Richaud, P., Ruffion, A., Salomon, L., Staerman, F. and Villers, A., Comite de Cancerologie de l’Association Française d’Urologie (2004) Prostatic Cancer. Progres en Urologie, 14, 913-955.

[6] Niang, L., Ndoye, M., Ouattara, A., Jalloh, M., Labou, I., Thia, I., Kouka, S.C., Diaw, J.J. and Gueye, S.M. (2013) Management of Prostate Cancer in Senegal: What Is Being Done? Progres en Urologie, 23, 36-41. http://dx.doi.org/10.1016/j.purol.2012.09.002

[7] Catalona, W., Richie, J., Ahman, F., Hudson, M., Scardino, P., Flanigan, R., Dekernion, J.B., Ratliff, T.L., Kavoussi, L.R. and Dalkin, B.L. (1994) Comparison of Digital Rectal Examination and Serum Prostate Specific Antigen. Journal of Urology, 151, 1283-1290.

[8] Stamey, T., Johnstone, I., McNeal, J., Ay, L.U. and Yemoto, C.M. (2002) Preoperative Serum Prostate Specific Antigen Levels. Journal of Urology, 167, 103-111. http://dx.doi.org/10.1016/S0022-5347(05)65392-X

[9] Villers, A., Rébillard, X., Soulié, M., Davin, J., Coloby, P., Moreau, J., Mejean, A., Irani, J., Coulange, C. and Mangin, P., French Association of Urology (2003) Prostate Cancer Screening. Progres en Urologie, 13, 209-214.

[10] Boccon-Gibod, L. Prostate Cancer: Diagnostic and Therapeutic Strategies. AKOS Encyclopedia of Medicine Practice, 5-0692.

[11] Descotes, J., Hubert, J., Rouvière, O. and Artignan, X. (2003) Urology Imaging: Contribution of Imaging in Prostatic Cancer. Progrès en Urologie, 13, 843-884.

[12] Sandhu, D., Mayor, P., Sambrook, P. and George, N. (1992) Outcome and Prognostic Factors in Patients with Advanced Prostate Cancer and Obstructive Uropathy. British Journal of Urology, 70, 412-416. http://dx.doi.org/10.1111/j.1464-410X.1992.tb15799.x

[13] Paule, B. and Cicco, A. (2001) Biphosphonates in the Treatment of Bone Metastasis of Prostatic Cancer. Progrès en Urologie, 11, 1205-1212.

[14] Prost, J., Gros, N., Bastide, C., Bladou, F., Serment, G. and Rossi, D. (2001) Correlation between Gleason Score of Prostatic Biopsies and the One of the Radical Prostatectomy Specimen. Progrès en Urologie, 11, 45-48.

[15] Rigaud, J., Le Normand, L., Karam, G., Glemain, P., Buzelin, J.M. and Bouchot, O. (2002) Prognostic Factors of Prostate Cancer Treated with First-Line Hormone Therapy. Progrès en Urologie, 12, 232-239.

[16] Salomon, L., Azria, D., Bastide, C., Beuzeboc, P., Cormier, L., Cornud, F., Eiss, D., Eschwege, P., Gaschignard, N., Hennequin, C., Molinie, V., Mongiat Artus, P., Moreau, J.L., Peneau, M., Peyromaure, M., Ravery, V., Rebillard, X., Richaud, P., Rischmann, P., Rozet, F., Staerman, F., Villers, A. and Soulie, M., Oncology Committee of the French Association of Urology (CCAFU) (2010) Recommendations Onco-Urology 2010: Prostate Cancer. Progrès en Urologie, 20, S217-S252. http://dx.doi.org/10.1016/S1166-7087(10)70042-7

[17] Walz, J., Marcy, M., Maubon, T., Brunelle, S., Laroche, J., Gravis, G., Salem, N. and Bladou, F. (2011) Real Time Elastography in the Diagnosis of Prostate Cancer: Comparison of Preoperative Imaging and Histology after Radical Prostatectomy. Progrès en Urologie, 21, 925-931. http://dx.doi.org/10.1016/j.purol.2011.04.006 